DOI: 10.46340/eppd.2020.7.4.11

Dmytro Yagunov, PhD in Public Administration, Meritorious Jurist of Ukraine ORCID ID: https://orcid.org/0000-0002-2822-2268

Vasyl' Stus Donetsk national university, Ukraine

\title{
PENITENTIARY POLICY IN THE EPOCH \\ OF GLOBALIZATION: «PRIVATE»VERSUS «PUBLIC» (CURRENT STATE OF PRISON PRIVATIZATION)
}

\author{
Дмитро Ягунов, к. н. держ. упр., заслужений юрист України \\ Донецький національний університет імені Василя Стуса, Україна \\ ПЕНІТЕНЦІАРНА ПОЛІТИКА В ДОБУ ГЛОБАЛІЗАЦІї: \\ «ПРИВАТНЕ» VERSUS «ПУБЛІЧНЕ» \\ (СУЧАСНИЙ СТАН В'ЯЗНИЧНОЇ ПРИВАТИЗАЦІї)
}

\begin{abstract}
The article is focused on the analysis of the current state of prison privatization in the United States and other Western countries. Although the practices of using prisoners by private actors have been known in the USA and some other countries for a long time, the phenomenon of prison privatization in its modern sense emerged only in the 1970s in response to the "war on crime" declared in the USA and, as a result, in response to serious increasing of the prison population. Harshening of criminal policy in many Western jurisdictions has led to the establishment of international private prison companies, many of which have entered the world market, offering their services to the governments of many countries. In modern conditions, the phenomenon of prison privatization more than seriously challenges the traditional notion of the execution of criminal punishments as a public function, which puts on the agenda the political, economic, and ethical problems associated with prison privatization. These problems are exacerbated by the fact that private prisons have not proved that delegating the "right to punish" from the state to private actors could solve the problems of contemporary national penitentiary systems (especially in the area of reducing the prison population.
\end{abstract}

Keywords: penitentiary system, penitentiary institution, prison, prison privatization, prisonindustrial complex, prison corporations, prison labor, social control, goals of punishment.

Вступ

Приватні засади каральної (пенітенціарної) політики не є новим явищем. Його коріння можна знайти ще у Стародавньому Світі. У подальшому в'язниці у країнах Свропи тривалий час перебували у приватних руках, де з ув'язнених стягувалася платня як за вимушене для них прибуття до в'язниці, так і за звільнення зі стану ув'язнення, не кажучи вже про оплачувану в'язнями їжу, постільну білизну та інші необхідні речі. Така практика, наприклад, мала місце у Британії аж до 1780 -х років, коли ув'язнених не почали масово депортувати до Австралії (за період з 1788 по 1868 рік у різні британські колонії на території Австралії британським урядом було примусово відправлено понад 162 тис. каторжників).

Упродовж великого проміжку часу європейські та північноамериканські кримінально-каральні практики пройшли шлях від приватної основи до виключно публічної, допоки у 1970-х роках не розпочався справжній бум в'язничної приватизації, який, в свою чергу, докорінно вплинув на пенітенціарну політику національних пенітенціарних систем та сутність ув'язнення як невід'ємної форми сучасного соціального контролю.

Проблематика поширення феномену в'язничної приватизації нерозривно пов'язана з процесами глобалізації та зміною сутності національної держави в добу глобалізації. Тому не можна на підкреслити слушність висловлення відомого німецького дослідника з питань глобалізації У. Бека щодо трансформації сутності національної держави: «Зараз відбувається творча руйнація «легітимного» світоустрою, за якого домінують національні держави» ${ }^{1}$.

${ }^{1}$ Бек, У. (2015). Влада $і$ контрвлада у добу глобалізації. Нова світова політична економія. Київ: Ніка-Центр, 31. 
Все це нерозривно пов'язано з функціонуванням пенітенціарних установ 3 традиційними для них цілями, де основною проблемою є так звана «криза реабілітаційного ідеалу» ${ }^{1}$ Так, У. Бек наголошує: «Сьогодні навіть теоретичні передумови «соціальної держави» та «соціального забезпечення» плавляться під пекучим сонцем глобалізації та відливаються у форми, які уможливлюють політичний вплив у відповідних сферах соціальних відносин. Те, що видає себе за універсалізм західного Просвітництва та прав людини, $\epsilon$ нічим іншим, як голос «мертвих, старих білих чоловіків», які ущемляють права етнічних та релігійних меншин, підносячи до абсолюту свою партійну «мета розповідь»².

Головна теза, що висуватися нами для аналізу сучасної пенітенціарної політики, полягає в тому, що приватний сектор не лише посів більш ніж суттєве місце в національних пенітенціарних системах, проте й значною мірою витіснив державу з традиційної (більше того - монопольної) для неї сфери виконання кримінальних покарань, утримання мігрантів та інших категорій осіб у різних за своєю природою та функціональною спрямованістю тотальних інституціях.

В'язнична приватизація виявилася надзвичайно привабливою ідеєю та залишається такою й понині у сучасному глобалізованому світі, ставлячи на порядку денному багато питань щодо природи кримінального покарання, функцій сучасної держави, сутності державної пенітенціарної політики та соціальної політики у сфері social inclusion злочинців та інших осіб, які вважаються такими, що становлять загрозу суспільному прядку та стабільності.

Сьогодні є доволі поширеними популістські ідеї, що державні чиновники є занадто негнучкими, державні структури є занадто бюрократичними, а державні в'язниці не забезпечують належним чином ані захисту суспільства від небезпечних осіб, ані реабілітації злочинців у цих в'язницях. До того ж платники податків не хочуть сплачувати податків на утримання дедалі більшої кількості «небезпечних злочинців», які уявляються «зайвим тягарем» для «чесних та законослухняних громадян».

Поширеною $є$ теза що «приватні в’язниці є більш дешевими, більш прозорими та підзвітними та більш інноваційними, аніж державні в'язниці» ${ }^{3}$. Також нерідко можна почути, що приватні компанії можуть бути більш ефективними з точки зору фінансової дисципліни та привносити більші інновації до своєї діяльності порівняно з державними установами. 3 огляду на зазначене вище існує доволі аргументована й достатньо грунтовна позиція, що «приватні в'язниці є більш безпечними та здоровими щодо реалізації реабілітаційних технологій для в'язничного населення» ${ }^{4}$.

Тому, здається, вихід з лабіринту кризи сучасних національних пенітенціарних систем та масового переповнення пенітенціарних установ, існує, і цей вихід начебто лежить на поверхні.

Такою чарівною паличною, здається, $є$ приватні в'язниці та взагалі в'язнична приватизація, яка сьогодні набула форми глобального феномену.

Феномен глобальної в’язничної приватизації поклав початок нескінченним дискусіям, де на порядку денному перебувають здебільшого два питання: 1) чи можна продавати «право карати» з огляду на моральні аспекти, атрибути та символістику каральної функції держави та природи кримінального покарання; 2) чи дійсно приватні в'язниці мають настільки явні переваги порівняно 3 аналогічними державними тотальними інституціями, щоб цю функцію держави масово передавати приватним акторам.

В цілому в’язнична приватизація може набувати різних форм, які дозволяють різні обсяги проникнення приватних акторів до сфери виконання кримінальних покарань та функціонування пенітенціарних установ:

1. Приватна компанія розробляє проектну документацію, будує в'язницю та управляє такою в'язницею відповідно до укладеного з урядом контракту.

2. Уряд будує нову в'язницю, яка передається в управління приватній компанії відповідно до укладеного з урядом контракту.

3. Вже існуюча державна в'язниця передається під управління приватній компанії відповідно до укладеного з урядом контракту.

\footnotetext{
${ }^{1}$ Ягунов, Д. (2011). Реабілітація злочинців як мета покарання: атавізм або вимушена необхідність? Актуальні проблеми держави і права, 60, 145-153.

${ }^{2}$ Бек, У. (2001). Что такое глобализация? Ошибки глобализма - ответы на глобализаиию. Москва: ПрогрессТрадиция.

${ }^{3}$ Glushko, A (2016). Doing Well And Doing Good: The Case For Privatising Prisons. Policy, 32, 1.

${ }^{4}$ Glushko, A (2016). Doing Well And Doing Good: The Case For Privatising Prisons. Policy, 32, 1.
} 
4. Певний перелік сервісів у державній в'язниці надається приватною компанією (охорона, безпека, спостереження, транспортування, охорона здоров'я, кейтерінг, пральні послуги, клінінг, реабілітаційні послуги, психологічна допомога, психіатричне лікування, звільнення від наркозалежності тощо).

5. Інші (комбіновані) варіанти.

\section{Сполучені Штати Америки}

Сполучені Штати Америки мають найбільш в'язничне населення у світі - як за абсолютними, так і за відносними показниками. Жодна демократична країна не примушувала перебувати за гратами стільки своїх та чужих громадян для цілей всеосяжного соціального контролю, як це роблять Сполучені Штати Америки. Тому є абсолютно недивним, що США є світовим лідером за обсягами феномену в'язничної приватизації, поширивши феномен в'язничної приватизації не лише на самі Сполучені Штати Америки, проте й на інші країни (Австралія, Британія, Південна Африка тощо). Так, станом на 2018 рік 8,5\% усіх американських ув'язнених утримувалися у приватних пенітенціарних установах.

Історія в’язничної приватизації у США має довгу історію, де вона набувала різних форм (надання медичних послуг, кейтерінг, професійна та технічна освіта, транспортування ув'язнених). Проте саме 1980-ті роки продемонстрували нові обличчя, сутність та обсяги в'язничної приватизації в США, благодатним підгрунтям для якої служили гасла й декларації більш жорстокої боротьби з наркозлочинністю та, як наслідок, зростання кількості ув'язнених, що було реалізовано у рамках політики Президента Р. Ніксона.

Американські штати запровадили політику «tough on crime», ухваливши численні закони, які забезпечили США найвищі в світі рейтинги щодо кількості ув'язнених. Це включало обов'язкові мінімальні строки ув'язнення, які унеможливлювали постановлення суддями більш м'яких вироків, а також скорочення обсягів застосування пробації та умовно-дострокового звільнення. Проте, напевно, головним були так звані «three strikes laws», які зобов'язували американських суддів ув'язнювати особу на тривалий строк внаслідок вчинення злочину втретє незалежно від тяжкості такого злочину.

Як наслідок, за період з 1970 - 2005 років кількість ув'язнених у США зросла на $700 \%$. Станом на 2011 рік, маючи 5\% світового населення, США водночас мали 25\% світового в'язничного населення ${ }^{1}$. За період 1980 - 2012 років загальна кількість ув'язнених у США зросла на $344 \%$, у той час коли загальна кількість населення зросла на $38 \%{ }^{2}$.

Подана нижче таблиця демонструє тенденції в'язничного населення у США за період 2000 2015 років $^{3}$ :

Таблиця 1

Тенденції в'язничного населення у США за період 2000 - 2015 років

\begin{tabular}{|c|c|c|}
\hline Рік & $\begin{array}{c}\text { Загальна кількість ув'язнених } \\
\text { (Сполучені Штати Америки) }\end{array}$ & $\begin{array}{c}\text { Кількість ув'язнених } \\
\text { на 100 тис. населення }\end{array}$ \\
\hline 2000 & 1937482 & 683 \\
\hline 2002 & 2033022 & 703 \\
\hline 2004 & 2135335 & 725 \\
\hline 2006 & 2258792 & 752 \\
\hline 2008 & 2307504 & 755 \\
\hline 2010 & 2270142 & 731 \\
\hline 2012 & 2228424 & 707 \\
\hline 2014 & 2217947 & 693 \\
\hline
\end{tabular}

\footnotetext{
${ }^{1}$ Banking on Bondage: Private Prisons and Mass Incarceration. November 2, 2011. American Civil Liberties Union. $<$ www.aclu.org $>$ (2020, липень, 12).

${ }^{2}$ Hadar, A. (2014). Are Private Prisons to Blame for Mass Incarceration and its Evils? Prison Conditions, Neoliberalism, and Public Choice. Fordham Urban Law Journal.<www.prisonstudies.org/country/united-states-america> (2020, липень, 12).

${ }^{3}$ World Prison Brief: USA. <www.prisonstudies.org/country/united-states-america> (2020, липень, 12).
} 
Водночас за період 1990 - 2009 років кількість ув'язнених уприватних в'язницях зросла приблизно на $1600 \%$. Станом на 2011 рік приватні в'язничні компанії відповідали приблизно за утримання 6\% в'язнів на рівні штатів, $16 \%$ федеральних в'язнів, і майже $50 \%$ усіх нелегальних мігрантів, затриманих федеральним урядом. Тільки у 2010 році лише дві найбільші приватні в'язничні компанії отримали майже 3 млрд. доларів прибутків ${ }^{1}$.

\section{Австралія}

Австралія стала другою у сучасному світі країною, яка після США розпочала аутсорсінг пенітенціарних послуг, проте з певними відмінностями порівняно із США.

Так, якщо у США хвиля в'язничної приватизації була наслідком масового переповнення американських в'язниць внаслідок проголошеної «war on crime», то в Австралії аналогічна хвиля на додаток до переповнення пенітенціарних установ була наслідком архітектурних потреб, адже більшість австралійських установ були побудовані більше століття тому, а тому не витримували критики правозахисників щодо умов тримання ув'язнених ${ }^{2}$.

Так, станом на 2017 рік рівень наповнення австралійських пенітенціарних установ становив $112,2 \%$, що природньо пояснювало звернення урядів відповідних австралійських штатів до можливостей в'язничної приватизації та відповідних провайдерів. Подана нижче таблиця демонструє тенденції в'язничного населення в Австралії за період $2000-2015$ років ${ }^{3}$ :

Таблиця 2

Тенденції в'язничного населення в Австралії за період 2000 - 2015 років

\begin{tabular}{|c|c|c|}
\hline Рік & $\begin{array}{c}\text { Загальна кількість ув'язнених } \\
\text { (Австралія) }\end{array}$ & $\begin{array}{c}\text { Кількість ув'язнених } \\
\text { на 100 тис. населення }\end{array}$ \\
\hline 2000 & 21714 & 114 \\
\hline 2002 & 22492 & 115 \\
\hline 2004 & 24171 & 121 \\
\hline 2006 & 25790 & 126 \\
\hline 2008 & 27615 & 130 \\
\hline 2010 & 29700 & 135 \\
\hline 2012 & 29383 & 130 \\
\hline 2014 & 33791 & 144 \\
\hline 2016 & 38845 & 161 \\
\hline 2018 & 42974 & 172 \\
\hline
\end{tabular}

Австралія відкрила свою першу приватну в'язницю ще у 1990 році (Borallon Correctional Centre) ${ }^{4}$. 32007 року управління цієї в'язницею здійснює Serco Group - потужний приватний провайдер послуг у сфері охорони здоров'я, транспорту, правосуддя, імміграції, оборони та публічних послуг.

У 2001 році було відкрито Acacia Prison - нову установу середнього рівня безпеки ${ }^{5} 3$ моменту відкриття до 2006 року управління цією в'язницею здійснювала Australian Integration Management Services Corporation (AIMS Corp), після чого також в'язниця перейшла до управління Serco Group.

Крім того, деякі імміграційні центри в Австралії також є приватними.

Найбільш відомим є Nauru Regional Processing Centre, який було відкрито у 2001 році за домовленістю між Президентом Науру та Урядом Австралії. Операторами Nauru Regional

\footnotetext{
${ }^{1}$ Banking on Bondage: Private Prisons and Mass Incarceration. November 2, 2011. American Civil Liberties Union. $<$ www.aclu.org $>$ (2020, липень, 12).

${ }^{2}$ Glushko, A. (2016). Doing Well And Doing Good: The Case For Privatising Prisons. Policy, 32, 1.

${ }^{3}$ World Prison Brief: Australia. <www.prisonstudies.org/country/australia> (2020, липень, 12).

${ }^{4}$ Borallon Training and Correctional Centre. <www.qld.gov.au/law/sentencing-prisons-and-probation/prisonsand-detention-centres> (2020, липень, 12).

${ }^{5}$ Acacia Prison. <www.wa.gov.au/organisation/department-of-justice/acacia-prison> (2020, липень, 12).
} 
Processing Centre були різні суб'єкти підприємницької діяльності (Broadspectrum, Wilson Security, Canstruct International, Nauruan Government Commercial Entity). У 2008 році діяльність центру призупинили, проте центр відновив свою роботу вже у 2012 році через зростання кількості шукачів притулку та прибулих до Австралії. У липні 2013 року у Nauru Regional Processing Centre стався бунт ув'язнених, в якому взяли участь 129 з 545 ув'язнених, який спричинив збитки на загальну суму понад 60 млн доларів ${ }^{1}$. Станом на серпень 2014 року Nauru Regional Processsing Centre утримував 1233 ув'язнених.

Станом на 2015 рік п’ять австралійських штатів запровадили у тій або іншій формі в'язничну приватизацію, причому окремі штати продемонстрували вельми яскравий приклад впливу приватних засад управління пенітенціарною системою.

У штаті Квінзленд нараховувалося 16 в'язниць, 3 яких 2 в'язниці були приватними: Arthur Gorrie Correctional Centre поблизу місті Brisbane та Southern Queensland Correctional Centre поблизу міста Gatton. Обидві установи управляються корпорацією $\mathrm{Serco}^{2}$.

У штаті Новий Південний Уельс нараховувалося 27 в'язниць, з яких 2 в'язниці управляються приватними акторами: Junee Correctional Centre поблизу міста Wagga Wagga та Parklea Correctional Centre у місті in North-Western Sydney. Станом на 214 рік ці дві в'язниці утримували 15,8\% усіх ув'язнених цього штату ${ }^{3}$.

У штаті Південна Австралія з 10 в'язниць лише 1 установа була приватною станом на 2015 рік (Mount Gambier Prison поблизу міста Mount Gambier).

У штаті Вікторія з 13 в'язниць 2 були приватними: Fulham Correctional Centre (компанія GEO Group) та Port Phillip (компанія G4S) ${ }^{5}$. У штаті Вікторія понад 33\% ув'язнених утримувалися саме у приватних закладах 6 .

У штаті Західна Австралія з 16 в’язниць 2 були приватними: Acacia Prison та Wandoo Reintegration Facility ${ }^{7}$.

Станом на 2016 рік з 94 австралійських візниць вже 10 були приватними.

Станом на 2018 рік понад 18,4\% австралійських ув'язнених утримувалися у приватних в'язницях.

\section{Нова Зеландія}

У Новій Зеландії проблема переповнення пенітенціарних установ також є гострою, про що свідчить зростання кількості ув'язнених з 148 на 100 тис. населення у 2000 році до 214 ув'язнених у 2018 році. Новозеландські в'язниці станом на середину 2019 року були заповнені на 93,8\%, що робить більш ніж актуальними питання в'язничної приватизації у цій країні.

Так, подана нижче таблиця демонструє тенденції в'язничного населення у Новій Зеландії за період $2000-2015$ років $^{8}$ :

У Новій Зеландії приблизно 10\% ув'язнених утримуються у приватних в'язницях (станом на 2016 рік).

В цілому Нова Зеландія пройшла шлях від бурхливого старту в’язничної приватизації до іiї заборони з подальшим відновленням приватних в'язниць.

Першою приватною новозеландською в'язницею була Auckland Central Remand Prison (нині Mt. Eden Corrections Facility), відкрита відповідно до контракту з Australasian Correctional Management (АСМ) у 2000 році.

\footnotetext{
${ }^{1}$ Review into the 19 July 2013 Incident at the Nauru Offshore Processing Centre.

$<$ https://reliefweb.int/report/nauru/review-19-july-2013-incident-nauru-offshore-processing-centre> (2020, липень, 12).

${ }^{2}$ Andrew, J. Roberts P. (2016). Prison Privatisation in Australia: The State of the Nation Accountability, Costs,

Performance and Efficiency. University of Sydney, Business School, 8.

${ }^{3}$ Andrew, J. Roberts, P. (2016). Prison Privatisation in Australia: The State of the Nation Accountability, Costs, Performance and Efficiency. University of Sydney, Business School, 20.

${ }^{4}$ Andrew, J. Roberts, P. (2016). Prison Privatisation in Australia: The State of the Nation Accountability, Costs,

Performance and Efficiency. University of Sydney, Business School, 31.

${ }^{5}$ Andrew, J. Roberts, P. (2016). Prison Privatisation in Australia: The State of the Nation Accountability, Costs,

Performance and Efficiency. University of Sydney, Business School, 38.

${ }^{6}$ Glushko, A. (2016). Doing Well And Doing Good: The Case For Privatising Prisons. Policy, 32, 1.

${ }^{7}$ Andrew, J. Roberts, P. (2016). Prison Privatisation in Australia: The State of the Nation Accountability, Costs,

Performance and Efficiency. University of Sydney, Business School, 49.

${ }^{8}$ World Prison Brief: New Zealand. <www.prisonstudies.org/country/new-zealand> (2020, липень, 12).
} 
Тенденції в'язничного населення у Новій Зеландії за період 2000 - 2015 років

\begin{tabular}{|c|c|c|}
\hline Рік & $\begin{array}{c}\text { Загальна кількість ув'язнених } \\
\text { (Нова Зеландія) }\end{array}$ & $\begin{array}{c}\text { Кількість ув'язнених на 100 тис. } \\
\text { населення }\end{array}$ \\
\hline 2000 & 5720 & 148 \\
\hline 2002 & 5738 & 145 \\
\hline 2004 & 6556 & 160 \\
\hline 2006 & 7595 & 181 \\
\hline 2008 & 7763 & 182 \\
\hline 2010 & 8604 & 198 \\
\hline 2012 & 8618 & 195 \\
\hline 2014 & 8571 & 190 \\
\hline 2016 & 9495 & 203 \\
\hline 2018 & 10435 & 214 \\
\hline
\end{tabular}

У 2004 році Уряд заборонив використання приватних в'язниць, і вже за рік п’ятирічний контракт з АСМ не було пролонговано. У 2010 році Уряд знову дозволив приватним компаніям управління в'язницями, внаслідок чого управління Auckland Central Remand Prison перейшло до корпорації Serco Group ${ }^{1}$.

Не так давно Serco Group отримала новий контракт на будівництво та управління новою в'язницею Auckland South Corrections Facility у Wiri, який передбачає суворі грошові санкції за недосягнення зниження показників рецидивної злочинності, визначених. В'язниця Auckland South Corrections Facility була відкрита у травні 2015 року з контрактом, що діє до 2040 року².

\section{Канада}

Канада в цілому становить приклад вельми поміркованого й навіть обережного схвалення феномену в'язничної приватизації навіть на фоні переповнення пенітенціарних установ (станом на 2015 рік рівень наповнення федеральних установ становив 98,8\%, установ провінцій - 104,4\%) ${ }^{3}$.

Так, в Канаді існувало всього три приватних пенітенціарних заклади, які врешті-решт повернулися під контроль Уряду.

Єдиною приватною установою для дорослих був Central North Correctional Centre y Penetanguishene (Онтаріо), який управлявся розташованою у США компанією Management and Training Corporation. Упродовж період приватного менеджменту (2001 - 2006) ця в'язниця максимального рівня безпеки була єдиною приватною установою для дорослих в Канаді. Причому контрактором виступала американська компанія Management and Training Corporation (MTC), розташована у штаті Юта.

Два закритих центри для підлітків управлялися приватними компаніями (обидва на рівні провінцій).

The Encourage Youth Corporation управляв Project Turnaround у місті Hillsdale (Онтаріо) відповідно до контракту з Урядом Онтаріо 31997 до 2004, після чого установа була закрита. Установа була призначена для тримання до 32 неповнолітніх злочинців, які вчинили особливо тяжкі злочини на кшталт озброєних нападів, незаконного позбавлення волі та незаконного поводження зі зброєю. Підлітки, засуджені за вбивства або згвалтування до цього центру не доставлялися. Project Turnaround використовувався як популярний у ті часи boot camp (тобто військовий табір, де перевиховання здійснювалося через застосування суворої військової дисципліни та правил, наближених до справжнього армійського життя).

\footnotetext{
${ }^{1}$ Auckland Central Remand prison to go private. <www.stuff.co.nz/national/3677414/Auckland-Central-Remandprison-to-go-private> (2020, липень, 12).

${ }^{2}$ Auckland South Corrections Facility (Kohuora). <www.serco.com/aspac/sector-expertise/justice/informationfor-friends-and-family/auckland-south-corrections-facility $>$ (2020, липень, 12).

${ }^{3}$ World Prison Brief: Canada. <www.prisonstudies.org/country/canada> (2020, липень, 12).
} 
У New Brunswick приватна компанія GEO Group побудувала та управляла Miramichi Youth Detention Centre відповідно до контракту з Департаментом громадської безпеки цієї провінції до 1990-х років (центр припинив свою дії внаслідок громадських протестів) ${ }^{1}$.

\section{Франція}

В цілому Франція не сприйняла американо-британський підхід, коли в'язниця могла б реалізовувати увесь спектр або більшість своїх функцій на приватних засадах. Французька пенітенціарна система адмініструється з великим залученням приватного сектора. Послуги 3 постачання продуктів харчування, білизни, прання, підтримання в'язниць в цілому делеговано приватним компаніям. Так само організація праці ув'язнених у в'язничних майстернях також делегована приватним акторам. Водночас усі функції з охорони та безпеки залишені за державними установами, що потягнуло за собою цілком природні конфліктні відносини між побутовим та безпековими секторами ув'язнення.

\section{Сполучене Королівство}

У XX столітті Сполучене Королівство стала першою європейською країною, яка започаткувала бізнес-орієнтовані в'язниці та дозволила отримання прибутку від управління приватними в'язницями.

У Британії першою приватною візницею стала Wolds Prison, відкрита у 1992 році відповідно до Criminal Justice Act 1991, який дозволив Секретареві внутрішніх справ укладати контракти 3 приватними в'язницями, яка управлялася корпорацією Group 4 Securicor (нині-G4S PLC), проте варто наголосити, що у 2013 році Wolds Prison знову стала державною.

Найновіша та водночас найбільша англійська в'язниця HM Prison Berwyn поблизу міста Wrexham управляється державою.

Станом на сьогодні понад 18\% ув'язнених в Англії та Уельсі утримуються у приватних пенітенціарних закладах. Для Шотландії цей показник складає 15,3\%.

На додаток, ряд імміграційних центрів також управляються приватними акторами.

Так, Harmondsworth Immigration Removal Centre та Colnbrook Immigration Removal Centre управляються приватною охоронною компанією Mitie Group PLC (великою британською компанією, яка переважно здійснює свою діяльність у сфері консультаційних послуг у сфері інфраструктури, енергозбереження та охорони здоров'я).

Yarl's Wood Immigration Removal Centre було відкрито у листопаді 2001 року з можливістю одночасного розміщення понад 400 осіб, що робило на той час його найбільшим центром в Свропі. Управління здійснювалося корпорацією Group 4 Falck

У Шотландії у 2007 році низка політичних сил оголосила про встановлення заборони на управління в'язницями приватними акторами. Як наслідок, нові в'язниці будуються та управляються на публічних засадах.

\section{Найвпливовіші гравці у сфері в'язничної приватизації}

Одним з найбільш впливових акторів та лідерів на полі в'язничної приватизації є CoreCivic (колишня Corrections Corporation of America (CCA)), заснована у 1983 році.

Станом на 2016 рік ця компанія посідала одну з найвищих сходинок серед усіх в'язничних корпорацій усвіті. Наразі корпорація управляє понад 65 пенітенціарними установами на федеральному та національному рівнях із загальною кількістю понад 90 тис. місць у 19 штатах США. Найбільшим інвестором CoreCivic виступає Vanguard Group (друга у США компанія у сфері інвестиційної діяльності, яка станом на 2015 рік володіла 14\% статутного фонду ССА) 2 .

Corrections Corporation of America, власне, започаткувала епоху в'язничної приватизації у США та світі, відкривши приватний імміграційний центр у місті Houston (штат Техас) ${ }^{3}$.

Вже у 1984 Corrections Corporation of America виборола новий контракт на управління в’язницею у графстві Shelby (штат Теннессі).

Наступного року федеральний суддя ухвалив рішення, яке забороняло приймати ув'язнених до переповнених в'язниць, на що одразу ж відреагувала Corrections Corporation of America, запропонувавши владі штату Теннессі 99-річний контракт на загальну суму майже 250 млн. доларів

\footnotetext{
${ }^{1}$ Ombudsman calls for closure of youth detention centre. $<$ www.cbc.ca/news/canada/new-brunswick/ombudsmancalls-for-closure-of-youth-detention-centre-1.660082> (2020, липень, 12).

${ }^{2}$ The Corrections Corporation of America, by the Numbers. <www.motherjones.com/politics/2016/06/cca-correctionscorperation-america-private-prisons-company-profile> $(2020$, липень, 12).

${ }^{3}$ Madison, Pauly. A Brief History of America's Private Prison Industry.

$<$ www.motherjones.com/politics/2016/06/history-of-americas-private-prison-industry-timeline $>$ (2020, липень, 12).
} 
за взяття в оренду усієї пенітенціарної системи штату Теннессі. Пропозиція Corrections Corporation of America щодо контролю над усіма пенітенціарними установами штату Теннессі мала ефект глибокого резонансу. Не зважаючи на опозицію з боку державних службовців та законодавчих структур штату, пропозиція ССА щодо таких обсягів в'язничної приватизації продемонструвала появу на полі пенологічних практик нових впливових приватних акторів, які кинули відкритий виклик державі у цій сфері державної політики ${ }^{1}$.

У 1989 році Corrections Corporation of America відкрила першу у країні приватну в'язницю для жінок - New Mexico Women's Correctional Facility (нині - Northwest New Mexico Correctional Facility) у місті Grants (штат Нью-Мексико) на 204 місць.

У 1990 році Corrections Corporation of America взяло під своє управління державну установу у місті Winn Parish (штат Луїзіана) - Winn Correctional Center (нині управляється за контрактом з приватною компанією LaSalle Corrections).

У 1992 році Corrections Corporation of America для Служби маршалів США відкрило Leavenworth Detention Center (штат Канзас), що становило вельми важливу подію в історії в'язничної приватизації, адже йшлося про перший в історії США контракт на управління в'язницею максимального рівня безпеки.

У 1992 році Corrections Corporation of America вийшла на британський ринок, відкривши Blackenhurst Prison у місті Worcestershire.

У 2016 році адміністрація Президента Б. Обами забезпечила Corrections Corporation of America контрактом на 1 млн. доларів на створення центру для шукачів притулку з Центральної Америки.

На другому місці перебуває GEO Group (колишня Wackenhut Corrections Corporation), заснована у 1984 році. Наразі корпорація управляє понад пенітенціарними установами із загальною кількістю понад 81 тис. місць.

Швидко набравши фінансового та політичного впливу, Wackenhut Corrections Corporation вже у 1992 році відкрила для себе австралійський та британські ринки, налагодивши різні форми співпраці у сфері в'язничної приватизації. Вже у 1993 році Wackenhut Corrections Corporation отримала контракт на розробку проектної документації, будівництво та управління Junee Correctional Centre для Департаменту виправних установ австралійського штату New South Wales.

У 1993 році Wackenhut Corrections Corporation відкрила найбільший в світі центр для утримання наркозалежних ув'язнених (Kyle Correctional Center) у штаті Tехас².

У 1997 році приватна компанія Cornell Corrections вперше отримало від Федерального бюро в'язниць США право управляти закладом на понад 2 тис. місць (Taft Correctional Institution) у штаті Каліфорнія, який, в свою чергу у 2010 році було придбано GEO Group.

У 1998 році Wackenhut Corrections Corporation відкрило першу в США приватну психіатричну лікарню (South Florida State Hospital).

У 1999 році Wackenhut Corrections Corporation відкрила для себе південноафриканський ринок, отримавши 25-річний контракт на розробку проектної документації, будівництво та управління Kutama Sinthumule Correctional Centre (KSCC).

У 2004 році GEO Group ще більше поширила свій вплив у Сполученому Королівстві, заснувавши GEO Group UK Ltd.

Крім того, приватними акторами, які займаються переважно управлінням цілісними установами є LaSalle Corrections, Management \& Training Corporation, Community Education Centers, Emerald Companies тощо.

Компанія Management and Training Corporation (MTC), розташована в американському штаті Юта, є третім за обсягами приватним в'язничним оператором у США: в іiї 12 установах утримується понад 31 тис. злочинців. Свого часу Management and Training Corporation виступала контрактором єдиної в Канаді приватної в'язниці максимального рівня безпеки для дорослих.

Компанія LaSalle Corrections управляє 18 виправними установами в американських штатах Луїзіана, Техас та Джорджія із загальною кількістю 13 тис. місць ${ }^{3}$.

Приватними установами для неповнолітніх опікуються такі компанії як G4S Youth Services, Youth Services International, Abraxas Youth \& Family Services (GEO), Cornerstone Programs, MidAtlantic Youth Services Corp.

\footnotetext{
${ }^{1}$ Madison, Pauly. A Brief History of America’s Private Prison Industry.

$<$ www.motherjones.com/politics/2016/06/history-of-americas-private-prison-industry-timeline $>(2020$, липень, 12).

${ }^{2}$ GEO Group History Timeline. <www.geogroup.com/history_timeline> (2020, липень, 12).

${ }^{3}$ LaSalle Corrections: Our Reach. <www.lasallecorrections.com/> (2020, липень, 12).
} 
У сфері пробаційних послуг функціонують такі компанії як Sentinel Offender Services, Judicial Corr. Services (Correct Care Solutions), Georgia Probation Services, CSRA Probation Services Inc.

Послуги з електронного моніторингу займаються BI Inc. (GEO), 3M Electronic Monitoring Inc., ISECUREtrac Corp., Satellite Tracking of People (Securus), Offender Management Services.

У Британії наразі 14 в'язниць управляються приватними компаніями, де найбільшим британським провайдером в'язничних послуг є корпорація Serco (HMP Ashfield, HMP Doncaster, HMP Dovegate, HMP Lowdham Grange, HMP Thameside).

Іншими британськими в'язничними гігантами є G4S Justice Services (HMP Altcourse, HMP Rye Hill, HMP Oakwood, HMP/YOI Parc) Ta Sodexo Justice Services (HMP Bronzefield, HMP Peterborough, HMP Northumberland, HMP/YOI Forest Bank) ${ }^{1}$.

В Австралії Serco управляє Acacia Prison у штаті Західна Австралія та Borallon Correctional Facility у штаті Квінзленд, а також Christmas Island Detention Centre та Villawood Detention Centre в Сіднеї.

У Новій Зеландії Serco управляє Mount Eden Remand Prison. Крім того, у березні 2012 року Serco отримала контракт на будівництво в'язниці у Wiri на 960 місць.

Оцінка переваг та недоліків приватних та державних в'язниць

Як це не дивно звучить не перший погляд, юстиції та правосуддя мають до такої оцінки вельми віддалене відношення.

3 формальної позиції критеріями для такого порівняння $\epsilon$, передусім, кількість ув'язнених, кількість персоналу (як security, так і соціальних працівників). Дослідження 2016 року, проведене Департаментом юстиції, що, дійсно, приватні в'язниці перевершують державні за окремими показниками у сфері безпеки. Проте водночас приватні в'язниці мали гірші відносні показники щодо нападів ув'язнених на персонал та інших ув'язнених. Так само приватні в'язниці були у вісім разім гіршими за кількістю вилучених в ув'язнених телефонів та вдвічі гіршими за показниками вилучених інших заборонених предметів.

Проте головним тут буде не скільки кількість ув'язнених, скільки «якість», а краще сказати рівень суспільної небезпеки, яку являють або можуть являти ув'язнені певної приватної або державної установи. Адже йдеться не тільки і не скільки про вартість витрат на кожного ув'язненого в день, скільки про відсутність втеч, нападів на персонал, внутрішніх конфліктів між ув'язненими тощо, самогубств, вбивств, згвалтувань та інших статевих злочинів різної тяжкості.

\section{Питання безпеки}

Численні дослідження, проведені різними американськими вченими, вказують на те, що «приватний сектор $є$ менш безпечний для ув'язнених», де кількість нападів ув' язнених на ув'язнених вдвічі перевищує аналогічний показник удержавних установах» ${ }^{2}$ Аналогічно, дослідження, проведене United States Department of Justice, вказало на те, що «приватні заклади мають значно більший показник нападів ув'язнених на ув'язнених та нападів ув'язнених на персонал, аніж державні установи» ${ }^{3}$.

Інше дослідження вказує на більшу кількість втеч та спроб втеч з ув'язнення саме у приватних установах ${ }^{4}$.

Відтак, коли ми ставимо на порядку денному питання поширення феномену в'язничної приватизації у контексті дискусії про приватні форми соціального контролю, варто нагадати, що тут, передусім, йдеться про джерела наповнення конкретних пенітенціарних установ найбільш небезпечним контингентом, що вже є здебільшого предметом політики, адміністрування, економіки, 3 якими дуже тісно межує корупція.

Щодо оцінки британських приватних пенітенціарних установ, то навіть на національному рівні дослідники вказують на брак вихідних даних для порівняння показників функціонування державних та приватних установ. Так, за даними HM Chief Inspector of Prisons, неможливо віддати пальму першості приватним або державним установам.

Інші дослідники вказують, що розрив за головним показником, за яким приватні установи 3'явилися як масовий феномен - менша вартість - сьогодні вже не є актуальним. Більше того, рівень

\footnotetext{
${ }^{1}$ Contracted-out prisons. <www.justice.gov.uk/about/hmps/contracted-out> (2020, липень, 12).

${ }^{2}$ Blakely, C., Bumphus, V. (2004). Private and Public Sector Prisons - A Comparison of Select Characteristics. Federal. Probation, 27, 30.

${ }^{3}$ Austin, J. Coventry, G. (2001). Emerging Issues on Privatized Prisons. U.S. Department of Justice.

${ }^{4}$ Camp, S. Gaes, G. (2001). Federal Bureau of Prisons, Growth and Quality of U.S. Private Prisons:

Evidence from a National Survey.
} 
фізичного насильства у приватних закладах нерідко оцінюється як набагато вищий порівняно здержавними установами. Те ж саме стосується випадків насильства з боку персоналу щодо ув'язнених (особливо статевого насильства).

Так, у серпні 2011 року, відповідно до даних американського Department of Justice, Edwin Rodriguez, офіцер з питань безпеки з приватного Willacy Detention Center, був визнаний винуватим у статевому насильстві під час виконання службових обов'язків щодо ув'язненої жінки ${ }^{1}$.

У 2009 році постало питання щодо статевого насильства щодо жінок з боку п'яти представників персоналу Otter Creek Correctional Center (штат Кентуккі), що мало наслідком засудження чотирьох обвинувачених з числа персоналу Otter Creek Correctional Center ${ }^{2}$.

У 2010 році Федеральне бюро розслідувань США провело розслідування діяльності Corrections Corporation of America після інциденту, що мав місце в Idaho Correctional Center, де ув'язнений втратив свідомість внаслідок нападу на нього з боку іншого ув'язненого. Згодом журналістами було оприлюднене відеозапис, який зафіксував, що персонал Idaho Correctional Center не лише не протидіяв нападу, проте й навпаки просто спостерігав на нападом, не вживаючи будь-яких заходів для протидії конкретному випадку небезпечного для життя насильства ${ }^{3}$. Внаслідок цього інциденту федеральний суддя стягнув 350 тис. доларів з Corrections Corporation of America в якості компенсації на правничі послуги за позовом щодо бездіяльності персоналу Idaho Correctional Center.

Крім того, у 2012 році вісім ув'язнених з Idaho Correctional Center подали до федерального суду позов, в якому звинуватили офіцерів Idaho Correctional Center, що останні фактично передали управління цієї пенітенціарною установою лідерам злочинних угруповань. У позові йшлося, що адміністрація Idaho Correctional Center на постійній основі використовувала членів відомого організованого злочинного угруповання Aryan Knights та інших небезпечних злочинців для залякування та терору загальної маси ув'язнених, перетворивши цю в'язницю на «гладіаторську арену». Так, ув' язнений Rowe Burningham звинуватив адміністрацію Idaho Correctional Center у тому, що його цілеспрямовано переселили до групи небезпечних злочинців насильницької спрямованості попри його заперечення та скарги ${ }^{4}$. Як наслідок цього скандалу у жовтні 2013 року корпорації Corrections Corporation of America було відмовлено в участі у тендері на управління цим центром на новий період, після чого управління Idaho Correctional Center повністю перейшло під контроль держави. 3 іншого боку, цей випадок не довід фіаско приватних в'язниць у порівнянні з державними, прикладом чого є вбивство у цьому ж виправному центрі ув'язненого Glenn Cox, причому на момент вбивства Idaho Correctional Center вже перебував під управлінням держави ${ }^{5}$.

У цьому контексті певні висновки можна зробити з аналізу судових справ за поданих проти Corrections Corporation of America позовів в американських судах, що з іншого боку відображають проблему, що аналізується: 16,1\% - умови ув'язнення та порушення прав людини; $15 \%$ - отримані тілесні ушкодження; 14,9\% - медична допомога; 8,6\% - умови праці; $5 \%$ - фізичні напади; 4,2\% застосування сили з боку персоналу; $3,7 \%$ - сексуальне насильство; $3,2 \%$ - смерть; $2,8 \%$ - сексуальне домагання ${ }^{6}$.

У 2012 році у Adams County Correctional Center (штат Micciciпi), який було призначено здебільшого для утримання нелегальних іммігрантів, звинувачених у повторному в'їзді до США після депортації (переважно з Мексики), стався бунт ув'язнених, який призвів до загибелі 1 офіцера та завдання тілесних ушкоджень 16 іншим офіцерам. Під час бунту 25 офіцерів було взято у заручники. За висновками розслідування стверджувалося, що бунт був пов'язаний з поганими умовами тримання та харчування. У свою чергу, Adams County Correctional Center також перебував під управлінням Corrections Corporation of America. Як наслідок, у серпні 2016 року представники

\footnotetext{
${ }^{1}$ Press Release, U.S. Department of Justice, Former Willacy Detention Contract Security Officer Pleads Guilty to Sexual Abuse of a Female Detainee in Texas (Aug. 4, 2011).

${ }^{2}$ Urbina, I. (2009). Hawaii To Remove Inmates Over Abuse Charges. New York Times.

37 Investigates: Inside the prison - isviolence down? <www.ktvb.com/article/news/local/only-on-7-inside-the-prisonis-violence-down/33936574> (2020, липень, 12).

${ }^{4}$ Violent Private Prison Called 'Gladiator School'. October 16, 2013. <www.courthousenews.com/violent-privateprison-called-gladiator-school> (2020, липень, 12).

${ }_{5}^{5}$ Idaho inmate death shines light on cellmate pairings at U.S. prisons. $<$ www.seattletimes.com/seattle-news/ idaho-inmate-death-shines-light-on-cellmate-pairings-at-u-s-prisons $>$ (2020, липень, 12).

${ }^{6}$ The Corrections Corporation of America by the Numbers. <www.motherjones.com/politics/2016/06/cca-correctionscorperation-america-private-prisons-company-profile> (2020, липень, 12).
} 
Міністерства юстиції оголосили, що Федеральне бюро в'язниць має припинити використання контрактних об'єктів, виходячи з того, що приватні в'язниці надають менш безпечні та менш ефективні послуги без істотних заощаджень ${ }^{1}$.

У 2015 році мало місце ескалація насильства у Cimarron Correctional Facility, розташованого у місті Cushing (штат Оклахома). Мало місце заворушення за участі понад 200 ув'язнених. У вересні 2015 року мала місце бійка між членами білошкірих в'язничних банд Irish Mob та Aryan Brotherhood, внаслідок якої загинуло четверо ув'язнених, а ще четверо отримали тілесні ушкодження ${ }^{2}$. Не зважаючи на таку резонансну подію, влада заявила, що все одно продовжить мати бізнес 3 приватними компаніями, мотивуючи продовження співпраці масовим переповненням місцевих в'язниць. Проте вже у травні 2017 року у цій же в'язниці мав місце напад ув'язнених на п'ятьох офіцерів. Напад стався близько вранці, коли в'язничний офіцер застосував перцевий спрей проти ув'язненого, який відмовився виконувати накази. Це призвело до того, що декілька ув'язнених напали на цього офіцера та інших офіцерів, які намагалися втрутитися у справу. Жоден ув'язнений не постраждав в інциденті, але п'ятьох співробітників було доставлено на лікування до сусідньої лікарні ${ }^{3}$.

\section{Економічні питання}

В цілому питання результатів порівняння економічних та фінансових показників залишається відкритим. Численні дослідження взагалі вказують на відсутність будь-якого чіткої відмінності між державними та приватними установами ${ }^{4}$.

Ряд досліджень вказують на переваги австралійських приватних пенітенціарних установ, підкреслюючи зниження вартості ув'язнення та підвищення позитивних відносин між ув'язненими та персоналом. Окремі джерела вказують, що аутсорсинг в'язничних сервісів приватним компаніям в Австралії суттєво знизив вартість витрат на кожного ув'язненого.

Так, за окремими джерелами, кожен ув'язнений у державній West Australian Jail коштує платникам податків 270 доларів, у той час коли аналогічна ціна в Acacia Prison складає всього 182 долари.

y New South Wales вартість утримання ув'язненого щодня у приватній в'язниці Junee Prison коштує 112 доларів порівняно з 170 доларами у будь-якій подібній державній в'язниці у тому ж штаті.

Проте критики подібного підходу вказують, що в Австралії, як в і в багатьох інших країнах, бракує незалежних досліджень, адже дослідження, які вказують на очевидні переваги державних в'язниць, нерідко містять ознаки упередженості.

Навпаки, у січні 2012 року Комісія з питань продуктивності- незалежний дослідний та консультативний орган австралійського уряду - оприлюднила Звіт про державні послуги за 2012 рік («Звіт про продуктивність»), де Розділ 8 зазначеного Звіту був присвячений саме пенітенціарним установам. Виявилося, що найвищі витрати на в'язниці припадають на Австралійську столичну територію і Тасманію, які не мають приватних пенітенціарних установ. Проте наступну сходинку посів штат Вікторія, в якому розташована найбільша кількість австралійських приватних пенітенціарних установ. Крім того, як не дивно, найдешевші виправні послуги, як виявилося, надавали пенітенціарні установи Північної території, де взагалі немає приватних в'язниць ${ }^{5}$. Водночас витрати штату Вікторія на пенітенціарну систему цього штату на $19 \%$ перевищували середній показник по країні для ії поточних витрат на одного ув'язненого в день.

Із зазначеного вище прикладу можна зробити висновок, що між приватизацією пенітенціарних установ та економією грошей платників податків відсутня кореляція, щоб стверджувати про очевидну перемогу або очевидну поразку в'язничної приватизації.

\footnotetext{
${ }^{1}$ Zapotosky, M. Harlan, C. (2016) Justice Department says it will end use of private prisons. August 19, 2016.

<www.washingtonpost.com/news/post-nation/wp/2016/08/18/justice-department-says-it-will-end-use-of-private-prisons> (2020, липень, 12).

${ }^{2}$ Video Surfaces In Deadly 2015 Cushing Prison Riot. <www.news9.com/story/5e345d623196993fcfd0527a/

video-surfaces-in-deadly-2015-cushing-prison-riot> $(2020$, липень, 12).

${ }^{3}$ Staff injured in riot at Cimarron Correctional Facility. May 17, 2017. <www.stwnewspress.com/news/staff-injuredin-riot-at-cimarron-correctional-facility/article_1484aacd-43a9-5b2d-a610-952d9651c379.html>. (2020, липень, 12).

${ }^{4}$ Hadar, A. (2014). Are Private Prisons to Blame for Mass Incarceration and its Evils? Prison Conditions, Neoliberalism, and Public Choice. Fordham Urban Law Journal. <www.prisonstudies.org/country/united-states-america> (2020, липень, 12).

${ }^{5}$ Alizzi, J. Private prisons in Australia: our 20 year trial. $<$ http://rightnow.org.au/opinion-3/private-prisons-in-australiaour-20-year-trial/> (2020, липень, 12).
} 
Щодо США, то у 2007 році американський Government Accountability Office (GAO) зробив висновок, що Федеральне бюро в'язниць США не є спроможним зробити об'єктивний висновок 3 приводу того, чи дійсно приватні в'язниці $є$ більш дешевими в управління порівняно $з$ державними установами.

Інші дослідження вказують, що в цілому приватні в'язниці максимального рівня безпеки у США є більш ефективними з точки зору економії коштів, у той час коли серед в'язниць мінімального та середнього рівня безпеки виграють державні установи ${ }^{1}$.

\section{Політичні аспекти в'язничної приватизації}

Крім того, враховуючи, що приватні в'язниці - це передусім великий бізнес та велика політика, то до сфери політичних відносин з питання наповнення в'язниць дедалі більшою кількістю ув'язнених додається навіть більш важливе питання - питання допуску до цього ринку конкурентів або, навпаки, витіснення з ринку вже існуючих акторів, що також є суто політичним питанням.

Проте, напевне, головним індикатором того, що питання в'язничної приватизації- це насамперед політика, а не юриспруденція, є принцип: «Чим більше доходів ви можете отримати 3 приватних в'язниць, тим більше приватних в'язниць ви будете намагатися створити разом із максимальним наповненням таких приватних в'язниць».

Так само виникає супутнє питання: «Чим більше ви створите приватних в'язниць з максимально великою кількістю ув'язнених, тим більше вам буде потребуватися персоналу для управління такими установами».

Відтак питання поширення в’язничної приватизації безпосередньо межує із сильним лобіюванням у двох напрямках.

По-перше, це пряме та опосередковане стимулювання парламентів та суддів до посилення суворості кримінальних покарань за різні злочини через нагнітання моральної паніки на кшталт «хвиля злочинності накриває наше місто (графство, штат, область, регіон тощо)», і «ми маємо щось діяти з такою навалою злочинності)». Наприклад, у 2010 році стало відомим, що корпорація Corrections Corporation of America за останні 20 років підготувала та спрямувала на розгляд різним політичним колам та політикам понад 85 проектів законів та резолюцій, спрямованих на посилення покарань, поширення імміграційних заборон та лобіювання приватних пенітенціарних закладів.

По-друге, це призводить до поширення застосування ув'язнення як уявного засобу убезпечення суспільства через «відокремлення поганих хлопців від чесних платників податків» та подальшої карцерації суспільства, у зв'язку з чим виникає проблема наявності дієвих механізмів стримування поширення таких негативних для суспільства процесів як масове ув'язнення та його негативні соціальні, психологічні, політичні, економічні наслідки.

Зазначене вище наочно демонструється тим, що навіть на фоні масового будівництва приватних в’язниць для США гострою залишаться проблема переповнення пенітенціарних установ.

Так, станом на 2017 рік пенітенціарні установи США були наповнені на 99,8\%, що вказує, що тотальна в'язнична приватизація аж ніяк не вирішує проблему, а, навпаки, загострює соціальні протиріччя у суспільстві внаслідок застосування занадто суворих каральних практик².

Відтак формула успіху в'язничної приватизації може бути визначена як «більше злочинів, більше прибутків», що обумовлює додаткове питання щодо дієвих механізмів стримування подібних бізнес-орієнтованих форм соціального контролю.

Політизація питання в'язничної приватизації у формі примушування суддів до заповнення приватних пенітенціарних установ можете сягати крайніх проявів навіть у країнах розвинутої демократії.

Так, свого часу Corrections Corporation of America в одному зі звітів зазначила таке: «Поблажливість у стандартах засудження або умовно-дострокового звільнення може негативно вплинути на попит на наші послуги» ${ }^{3}$.

Корпорація GEO Group ідентифікувала свої ризики приблизно подібним чином: «Наше зростання залежить від нашої спроможності зберігати старі та укладати нові контракти на управління

\footnotetext{
${ }^{1}$ Hadar, A. (2014). Are Private Prisons to Blame for Mass Incarceration and its Evils? Prison Conditions, Neoliberalism, and Public Choice. Fordham Urban Law Journal. <www.prisonstudies.org/country/united-states-america> .

${ }^{2}$ World Prison Brief: USA. <www.prisonstudies.org/country/united-states-america > (2020, липень, 12).

${ }^{3}$ Banking on Bondage: Private Prisons and Mass Incarceration. November 2, 2011. American Civil Liberties Union. $<$ www.aclu.org $>$ (2020, July, 12).
} 
виправними та психіатричними закладами, що не перебуває у межах нашого безпосереднього контролю. Будь-які прояви декриміналізації злочинів, пов'язаних з обігом наркотичних та подібних речовин може вплинути на кількість заарештованих, обвинувачених та засуджених осіб, що врештірешт призведе до скорочення кількості закритих закладів. Так само, зниження показників злочинності може призвести до скорочення ув'язнення. Імміграційні реформи також можуть безпосередньо впливати на наш матеріальний стан» ${ }^{1}$.

Тому в розрізі подібних позицій вельми недивним є відомий скандал, пов'язаний із підкупом двох суддів за ухвалення більш суворих вироків для підлітків («kids for cash scandal»), коли двоє суддів з Luzerne County Court of Common Pleas зі штату Пенсильванія (Michael Conahan та Mark Ciavarella) були визнані винуватими в отриманні неправомірної вигоди від приватної в'язничної компанії за штучне незаконне наповнення двох приватних центрів для неповнолітніх злочинців.

Обидва судді були звинувачені в отриманні декількох мільйонів доларів за виконання злочинної угоди між суддями та приватними установами. Судді також бути звинувачені у «спрямовуванні неповнолітніх осіб до приватних закритих центрів внаслідок існування фінансового інтересу за умов, коли навіть офіцери ювенальної пробації не рекомендували поміщення таких неповнолітніх осіб до установ закритого типу». На додаток судові рішення ухвалювалися за відсутності належної правничої допомоги. Внаслідок викриття подібної схеми Верховної Суд штату Пенсильванія був вимушений переглянути сотні вироків до позбавлення волі.

Щодо просто лобіювання, то за різними підрахунками Corrections Corporation of America упродовж період з 1999 - 2020 років витрачала щонайменше 1,4 мільйони доларів щороку на лобіювання своїх інтересів на федеральному рівні. За період 2003 - 2011 років Corrections Corporation of America (нині - CoreCivic) найняла 199 професійних лобістів у 32 штатах. За той же час GEO Group (колишня Wackenhut Corrections Corporation) найняла 72 професійних лобісти у 17 американських штатах ${ }^{2}$.

\section{Етична складова в'язничної приватизації: в'язнично-індустріальний комплекс як політична проблема}

Приватні в'язниці - це великий бізнес. Тому є природнім, що для бізнесу головною метою $є$ мінімізація видатків та максимізація прибутків. Проте реабілітація злочинців, яку зазвичай проголошено якщо не першою, то обов'язково однієї з головних цілей кримінального покарання та місією функціонування сучасних пенітенціарних установ, завжди $є$ достатньо дорогим та витратним заданням. Відтак природне переслідування певною приватною в'язничною компанією мети збільшення прибутків неодмінно буде стикатися з дилемою «прибутки проти реабілітація злочинців ", де перевага, звичайно, буде віддаватися першому.

В цілому, можна сказати, що сутність, а головне - наслідки в'язничної приватизації як політичного феномену, мало змінилося з XVIII століття.

Так, у XVIII столітті приватні актори, які управляли в'язницями, не мали стимулів, щоб витрачати гроші на ув'язнених, надаючи останнім мізерні майки та поміщуючи останніх у жахливі умови. Так само у XIX столітті підрядники, які «орендували» ув'язнених на день за системою convict lease system, не мали матеріальної зацікавленості, щоб утримувати їх в умовах, які б були безпечними для ув'язнених. Вже у XIX столітті приватні тюремні оператори в умовах домінування філософії прав людини та наявності міжнародних стандартів прав людини, були зобов'язані покращувати умови тримання ув'язнених до певного мінімального рівня, який б перевищував мінімальний рівень страждань та не сягав би рівня нелюдського поводження. Проте навіть така «турбота» продиктована намаганням максимально скоротити видатки («to cut corners») можлива за рахунок як громадської безпеки, так і умов ув'язнення.

В'язнична приватизація як політико-економічний феномен не може існувати у політичному вакуумі. Разом з в'язничною приватизацією виникли та продовжують існувати могутні групи акторів, які посіли вагоме місце у структурі національних систем кримінальної юстиції. Взаємозв'язки між приватними в'язничними корпораціями, постачальниками послуг для в'язничних корпорацій, постачальникам технічних засобів спостереження та контролю, профспілок офіцерів приватних в'язничних корпорацій, лобістів та юристів приватних в'язничних корпорацій з одного боку,

\footnotetext{
${ }^{1}$ Banking on Bondage: Private Prisons and Mass Incarceration. November 2, 2011. American Civil Liberties Union. $<$ www.aclu.org $>$ (2020, July, 12).

${ }^{2}$ National Institute on Money In State Politics, Client Summary: GEO Group.

$<$ www.followthemoney.org/database/lobbyistclient.phtml?lc $=100516 \& y=0>(2020$, July, 12)
} 
та державними акторами, з іншого боку, зумовили появу нового феномену, який отримав назву в'язнично-індустріального комплексу (prison-industrial complex).

Цей феномен американський дослідник Eric Schlosser визначив як «сукупність бюрократичних, політичних та економічних інтересів, що заохочує зростання обсягів та витрат на ув'язнення, незалежно від дійсної потреби в таких обсягах». Далі Eric Schlosser продовжує: «В'язничноіндустріальний комплекс - це не лише сукупність інтересів та інституцій. На додаток це - стиль мислення. Приманка великих грошей розбещує національну систему кримінальної юстиції, замінюючи соціальну орієнтацію державної служби прагненням до отримання більших прибутків» ${ }^{\text {. }}$

Інша американська авторка (Hadar Aviram) висловлює слушну думку, що проблемою $є$ не скільки в'язнична приватизація як така, скільки причини, які зумовили появу феномену в'язничної приватизації. Ці причини, на переконання авторки, криються у переорієнтації системи кримінальної юстиції на отримання матеріальних вигід, у той час коли соціальні та етичні аспекти ув'язнення та в цілому кримінальної юстиції залишено на другому місці².

Більше того, окремі автори аргументовано вказують на феномен в'язничної приватизації як неприховану сучасну форму рабства, дещо обмеженого стандартами прав людини, які надають їй дещо гуманного обличчя, проте, все одно, не змінюють рабовласницької сутності в'язничної приватизації

По мірі зростання кількості в'язничного населення зростає роль дрібного та середнього бізнесу, який постачає для приватних пенітенціарних установ ліки, продукти харчування та надає різні послуги. Як наслідок, наприклад, американська в'язнична система опосередковано є третім за обсягами працедавцем у світі.

Приватні в’язничні корпорації стали та продовжують бути каналізаторами переповнення в'язниць та створення глобалізованого тотального карцерного суспільства. Приватні в'язничні корпорації отримують від держави певну суму за кожен день перебування ув'язненого у приватній пенітенціарній установі. Оскільки лише велика кількість ув'язнених є запорукою отримання великих прибутків, нерідко договори між державами та приватними компаніями визначають конкретний рівень наповнення конкретної в'язниці, яку держава зобов'язана забезпечити шляхом винесення вироків до позбавлення волі. Hadar Aviram слушно зазначає, що «у такому вигляді тюремне населення та тюремне ув'язнення стають функцією не регулювання рівня злочинності та громадської безпеки, а попиту та пропозиції та договірних зобов'язань» ${ }^{4}$.

Причому така сфера виробничих відносин є вельми зручною для тих, хто нею управляє: «Для приватного бізнесу в'язнична праця - це як горщик із золотом. Жодних страйків. Ніяких профспілкових організацій. Ніяких пільг за шкоду здоров'ю, страхування від безробіття або компенсацій працівникам. Відсутні мовні бар'єри. Левіафан будує нові в’язниці-фабрики на тисячах страшних гектарів за високими мурами. Ув'язнені здійснюють телефонні бронювання, вирощують свиней та іншу худобу, лопають гній, виготовляють плати для електронно-обчислювальних машин, роблять лімузини та інші автомобілі, водяні ліжка та навіть нижню білизну для Victoria's Secret - все це за частку вартості «вільної праці» 5 .

За різними даними велика кількість світових гігантів у тій або іншій мірі використовує працю ув'язнених ${ }^{6}$. Дослідники до таких компаній відносять Walmart, Microsoft Corporation, Starbucks, BP, Nintendo, Unicor, Dell, Eddie Bauer, Kmart, Boeing, Verizon, Verizon, McDonald's, Sprint Corporation, Honda Motor Company, Intel, Nordstrom, Motorola, Exxon Mobil, Bank of America Corporation, Procter \&

\footnotetext{
${ }^{1}$ Schlosser, E. The Prison-Industrial Complex. <www.theatlantic.com/magazine/archive/1998/12/the-prison-industrialcomplex/304669> (2020, July, 12).

${ }^{2}$ Hadar, A. (2014). Are Private Prisons to Blame for Mass Incarceration and its Evils? Prison Conditions, Neoliberalism, and Public Choice. Fordham Urban Law Journal. <www.prisonstudies.org/country/united-states-america>.

${ }^{3}$ Kai, J. (2013). The Disgrace of America's prison-industrial complex. $<$ www.pressreader.com/canada/national-postnational-edition/20130323/281801396410269> (2020, July, 12).

${ }^{4}$ Hadar, A. (2014). Are Private Prisons to Blame for Mass Incarceration and its Evils? Prison Conditions, Neoliberalism, and Public Choice. Fordham Urban Law Journal. <www.prisonstudies.org/country/united-states-america>.

${ }^{5}$ Davis, A. (1998). Masked Racism: Reflections on the Prison Industrial Complex.

$<$ www.colorlines.com/archives/1998/09/masked_racism_reflections_on_the_prison_industrial_complex.html $>$ (2020, July, 12)

${ }^{6} 12$ Major Corporations Benefiting from the Prison Industrial Complex $<\mathrm{http}: / /$ maltajusticeinitiative.org/12-majorcorporations-benefiting-from-the-prison-industrial-complex-2/> (2020, July, 12).
} 
Gamble, Shell Oil Company, United Parcel Service, Hewlett-Packard, Caterpillar, IBM, Johnson \& Johnson, Cargill, Mary Kay, United Airlines, State Farm Insurance, American Express ${ }^{1}$.

Одним з головних наслідків поширення обсягів в'язнично-індустріального комплексу - це розмивання кордонів між «приватним» та «публічним»². У той же час «право карати» в умовах сучасної держави та верховенства прав людини має бути виключно публічним.

\section{Імміграція та приватні в'язничні корпорації}

Останнім часом дедалі більшої актуальності набувають питання переміщення великих мас населення та, відповідно, імміграційних законів, які нерідко стають дедалі більш жорсткими. Власне, одним з найбільш улюблених гасел, що нерідко вживаються політиками на національному на місцевому рівнях у багатьох країнах - це «захист країни та суспільства від небезпечних мігрантів». Відповідно, на фоні традиційних форм в'язничної приватизації дедалі більшого поширення набув феномен приватизації закритих центрів для іммігрантів, що є надзвичайно привабливим сектором для в'язничних корпорацій.

Так, ще 1987 року Wackenhut Corrections Corporation (нині - the GEO Group) отримала перший контракт на управління закритим центром для нелегальних мігрантів ${ }^{3}$. За період з $1994-2011$ років кількість мігрантів, які утримувалися у закритих міграційних центрах у США, зросла на $457 \%$. Відповідно 49\% мігрантів в середньому утримувалися саме у приватних імміграційних центрах.

Приватні імміграційні центри також стають центром уваги дослідників та критиків, які вказують на ті ж самі проблеми, що характерні для приватних в'язниць: обіцяні послуги не $\epsilon$ дешевими, а рівень безпеки не $є$ таким, яким його зображували при підписанні відповідних контрактів з урядами.

Так, у 2018 році британський HM Chief Inspector of Prisons визнав умови триманні людей y Harmondsworth Immigration Removal Centre, що управляються приватною охоронною компанією Mitie Group PLC, такими, що не відповідають вимогам безпеки та поваги до гідності. Центр перевірявся ще у 2015 році, проте не зважаючи на певні покращення, все одно якість послуг, що надаються центром, були визнано неналежними. У відповідному звіті HM Chief Inspector of Prisons було відзначено, що замало уваги приділяється до зниження посттравматичного стресу внаслідок приміщення людей до центру. Хоч рівень насильства був невисокий, загальна атмосфера у центрі надавала підстави говорити про наближення до мінімального рівня жорстокості. Поширеною була практика вживання наркотиків. Проте головне, що було зазначено, це те, що центр не $є$ власне в'язницею, у той час коли деякі аспекти безпеки більше нагадували такі, що є характерними саме для пенітенціарних установ.

Обмеження проявів та обсягів в'язничної приватизації

Звичайно, що подібне зростання обсягів в'язничної приватизації та національному та глобальному рівнях не може перебувати поза увагою багатьох політиків, соціологів, економістів та дослідників, що створює різні форми лобіювання, спрямованого на звуження використання приватизації пенітенціарних установ у тих чи інших формах.

Так, деякі американські штати запровадили різні форми обмежень на поширення феномену в'язничної приватизації.

У 1990 році американські штати Іллінойс та Нью-Йорк запровадили закони, які забороняють приватизацію в'язниць та будь-яких супутніх послуг, що стосуються функціонування пенітенціарних установ. У 2001 році штат Луїзіана запровадив мораторій на приватні в'язниці. У 2001 році штати Дакота та Орегон ухвалили закони, які забороняють транспортування ув'язнених поза межі штату, у тому числі для наповнення приватних пенітенціарних установ. У 2001 році штат Небраска ухвалив закон, який зобов’язує приватні в'язниці функціонувати за однаковими стандартами, що і державні установи.

\section{Висновок}

Беручи до уваги переважно зарубіжний (переважно американський, британський, австралійський та новозеландський) досвід в'язничної приватизації, багато дослідників обгрунтовано розглядають приватні в'язниці та їх операторів як такі, що є корумпованими, занадто секретними та

\footnotetext{
${ }^{1}$ Carlton Genevieve. 49 Large American Companies That Use Prison Labor. <www.ranker.com/list/companiesin-the-united-states-that-use-prison-labor/genevieve-carlton $>$ (2020, July, 12)

${ }^{2}$ Schlosser, E. The Prison-Industrial Complex. <www.theatlantic.com/magazine/archive/1998/12/the-prisonindustrial-complex/304669> (2020, July, 12).

${ }^{3}$ MadisonБ Pauly. A Brief History of America's Private Prison Industry.

<www.motherjones.com/politics/2016/06/history-of-americas-private-prison-industry-timeline/> (2020, July, 12).
} 
морально збанкрутілими з огляду на цілі покарання, що вважаються традиційними для сучасних національних пенітенціарних систем, які відчули глибинний вплив філософії прав людини та відповідних міжнародних стандартів прав людини.

В цілому аспекті прибічникам в'язничної приватизації можна протиставити вельми просту ідею: якщо ув'язнення як таке має мінімальний ефект щодо запобігання злочинності (якщо не сказати більше), то чи існують моральні підстави розглядати феномен поширення в'язничної приватизації як певне благо в системі політичних відносин?

Немає сумнівів, що уряди укладають договори з приватними в'язничними провайдерами внаслідок вимушеної необхідності, враховуючи складні вимоги сучасних національних пенітенціарних систем. Однак існує небезпека, що навички, можливості та досвід приватних в'язничних корпорацій - навіть там, де вони можуть бути начебто «ефективними», насправді $є$ суто технічними, позбавленими етичних стандартів, культури соціальної відповідальності та культури прав людини.

Питання в’язничної приватизації - це не лише питання моралі та етики. Це, передусім, питання фінансового тягаря платників податків, адже приватні в'язничні компанії фінансуються саме здержавного бюджету внаслідок отримання відповідних контрактів від національних або регіональних урядів. Як наслідок, поширення ув'язнення як соціального феномену створює додаткове навантаження на державний бюджет, окрім того, що сприяє позбавленню свободи людей у рекордній кількості по всьому світі.

У цьому контексті на особливу увагу також заслуговує й те, що тюремне ув'язнення - це «найдорожчій спосіб зробити поганий людей ще гіршими». Масова інкарцерація - це соціальна хвороба, яка приносить користь для приватної в'язничної індустрії, яка витягує все більше доларів 3 платників податків з державних бюджетів, коли уряди відправляють ув'язнених до приватних закладів у все більшій кількості.

Крім того, подібне, на перший погляд, вирішення проблеми ув'язнення, коли злочинців відправляють начебто до «кращих закладів з кращими умовами» несе небезпеку максимального розбалансування відповідної держави у пенітенціарній сфері.

Так, якщо держава не «тренує» «м'язи» національної пенітенціарної системи, то вони починають «атрофуватися», внаслідок чого держава може взагалі втратити усі важелі впливу над цієї сферою соціального контролю.

Якщо держава не може забезпечити нормальні умови тримання ув'язнених у пенітенціарних установах та дотримання прав людини у державних закладах, то чи зможе держава вимагати такого від приватних акторів, місія яких полягає виключно в отриманні прибутків?

\section{References:}

1. 12 Major Corporations Benefiting from the Prison Industrial Complex. $<$ http://maltajusticeinitiative.org/12-majorcorporations-benefiting-from-the-prison-industrial-complex-2/> (2020, July, 12). [in English].

2. 7 Investigates: Inside the prison - isviolence down? <www.ktvb.com/article/news/local/only-on-7-inside-theprison-is-violence-down/33936574> (2020, July, 12). [in English].

3. Acacia Prison. <www.wa.gov.au/organisation/department-of-justice/acacia-prison> (2020, July, 12).

4. Alizzi, J. Private prisons in Australia: our 20 year trial. <http://rightnow.org.au/opinion-3/private-prisons-inaustralia-our-20-year-trial/> (2020, July, 12). [in English].

5. Andrew, J. Roberts, P. (2016). Prison Privatisation in Australia: The State of the Nation Accountability, Costs, Performance and Efficiency. University of Sydney, Business School. [in English].

6. Auckland Central Remand prison to go private. <www.stuff.co.nz/national/3677414/Auckland-Central-Remandprison-to-go-private> (2020, July, 12). [in English].

7. Auckland South Corrections Facility (Kohuora). <www.serco.com/aspac/sector-expertise/justice/informationfor-friends-and-family/auckland-south-corrections-facility> (2020, July, 12). [in English].

8. Austin, J. Coventry, G. (2001). Emerging Issues on Privatized Prisons. U.S. Department of Justice. [in English].

9. Banking on Bondage: Private Prisons and Mass Incarceration. November 2, 2011. American Civil Liberties Union. $<$ www.aclu.org $>$ [in English].

10. Blakely, C., Bumphus, V. (2004). Private and Public Sector Prisons - A Comparison of Select Characteristics. Fed. Probation, 27, 30. [in English].

11. Borallon Training and Correctional Centre. <www.qld.gov.au/law/sentencing-prisons-and-probation/prisons-anddetention-centres> (2020, July, 12). [in English].

12. Camp, S. Gaes, G. (2001). Federal Bureau of Prisons, Growth and Quality of U.S. Private Prisons: Evidence from a National Survey. [in English]. 
13. Carlton, Genevieve. 49 Large American Companies That Use Prison Labor. <www.ranker.com/list/companies-inthe-united-states-that-use-prison-labor/genevieve-carlton> (2020, July, 12). [in English].

14. Contracted-out prisons. <www.justice.gov.uk/about/hmps/contracted-out> (2020, July, 12). [in English].

15. Davis, Angela (1998). Masked Racism: Reflections on the Prison Industrial Complex. <www.colorlines.com/archives/1998/09/masked_racism_reflections_on_the_prison_industrial_complex.html> (2020, July, 12). [in English].

16. GEO Group History Timeline. <www.geogroup.com/history_timeline> (2020, July, 12). [in English].

17. Glushko, A (2016). Doing Well And Doing Good: The Case For Privatising Prisons. Policy, 32, 1. [in English].

18. Hadar, A. (2014). Are Private Prisons to Blame for Mass Incarceration and its Evils? Prison Conditions, Neoliberalism, and Public Choice. Fordham Urban Law Journal. <www.prisonstudies.org/country/united-statesamerica $>$ [in English].

19. Idaho inmate death shines light on cellmate pairings at U.S. prisons. <www.seattletimes.com/seattle-news/ idaho-inmate-death-shines-light-on-cellmate-pairings-at-u-s-prisons $>$ (2020, July, 12). [in English].

20. Kai, J. (2013). The Disgrace of America's prison-industrial complex. <www.pressreader.com/canada/nationalpost-national-edition/20130323/281801396410269> (2020, July, 12). [in English].

21. LaSalle Corrections: Our Reach. <www.lasallecorrections.com/> (2020, July, 12). [in English].

22. Madison, P. (2016). A Brief History of America's Private Prison Industry. $<$ www.motherjones.com/politics/2016/06/history-of-americas-private-prison-industry-timeline> (2020, July, 12). [in English].

23. National Institute on Money In State Politics, Client Summary: GEO Group. $<$ www.followthemoney.org/database/lobbyistclient.phtml?lc=100516\&y=0> (2020, July, 12). [in English].

24. Ombudsman calls for closure of youth detention centre. $<$ www.cbc.ca/news/canada/new-brunswick/ombudsmancalls-for-closure-of-youth-detention-centre-1.660082> (2020, July, 12). [in English].

25. Press Release, U.S. Department of Justice, Former Willacy Detention Contract Security Officer Pleads Guilty to Sexual Abuse of a Female Detainee in Texas (Aug. 4, 2011). [in English].

26. Review into the 19 July 2013 Incident at the Nauru Offshore Processing Centre. $<$ https://reliefweb.int/report/nauru/review-19-july-2013-incident-nauru-offshore-processing-centre> (2020, July, 12). [in English].

27. Schlosser, E. (1998). The Prison-Industrial Complex. <www.theatlantic.com/magazine/archive/1998/12/ the-prison-industrial-complex/304669> (2020, July, 12). [in English].

28. Staff injured in riot at Cimarron Correctional Facility (2017). <www.stwnewspress.com/news/staff-injured-in-riotat-cimarron-correctional-facility/article_1484aacd-43a9-5b2d-a610-952d9651c379.html>. [in English].

29. The Corrections Corporation of America by the Numbers. <www.motherjones.com/politics/2016/06/ cca-corrections-corperation-america-private-prisons-company-profile> (2020, July, 12). [in English].

30. Urbina, I. (2009). Hawaii To Remove Inmates Over Abuse Charges. New York Times. [in English].

31. Video Surfaces In Deadly 2015 Cushing Prison Riot. <www.news9.com/story/5e345d623196993fcfd0527a/ video-surfaces-in-deadly-2015-cushing-prison-riot> (2020, July, 12). [in English].

32. Violent Private Prison Called 'Gladiator School'. October 16, 2013. <www.courthousenews.com/ violent-private-prison-called-gladiator-school $>$ (2020, July, 12). [in English].

33. World Prison Brief: Australia. <www.prisonstudies.org/country/australia> (2020, July, 12). [in English].

34. World Prison Brief: Canada. <www.prisonstudies.org/country/canada> (2020, July, 12). [in English].

35. World Prison Brief: New Zealand. <www.prisonstudies.org/country/new-zealand $>$ (2020, July, 12). [in English].

36. World Prison Brief: USA. <www.prisonstudies.org/country/united-states-america> (2020, July, 12). [in English].

37. Zapotosky, M. Harlan, C. (2016). Justice Department says it will end use of private prisons. $<$ www.washingtonpost.com/news/post-nation/wp/2016/08/18/justice-department-says-it-will-end-use-of-privateprisons $>$ (2020, July, 12). [in English].

38. Bek, U. (2015). Vlada i kontrvlada u dobu globalizatsii. Nova politychna ekonomiya [Power and counterpower in the age of globalization. New political economy]. Kyiv. [in Ukrainian].

39. Bek, U. (2001). Chto takoe globalizatsiya? Oshybki globalizma - otvety na globalizyatsiu [What is globalization? The mistakes of globalism - answers to globalization]. Moscow. [in Russian].

40. Yagunov, D. (2011). Reabilitatsiya zlochyntsiv yak meta pokarannya: atavizm abo vymushena neobhidnist [Rehabilitation of criminals as a goal of punishment: atavism or forced necessity]. Aktualni problemy derzhavy i prava [Current issues of state and law], iss. 60, 145-153. [in Ukrainian]. 